\title{
An Evaluation of Public Power in Hydropower Planning in Van (Turkey)
}

\author{
Van (Türkiye)'da Hidro-Enerji Planlamasında \\ Kamunun Gücüne Yönelik Bir Değerlendirme
}

\author{
Emel BAYLAN
}

\section{ABSTRACT}

The number of planned and installed hydroelectric power plants has increased dramatically in the last 15 years in Turkey. The local natural and socio-cultural domains of the subject landscapes, however, have mostly been ignored in the decision-making and implementation processes for these plant projects. As a consequence, hydroelectric plants installed in the water-rich regions of the country had adverse effects on river landscapes. Local and national water and landscape stakeholders have confronted each other in several platforms as a result of their conflicting needs and interests. River landscapes in the province of Van, located in eastern Anatolia, are also faced with similar threats and disagreements as a result of multiple, river-type hydropower plants that are to be installed in the near future. A collaborative decision-making approach that would allow for active stakeholder participation and that would support negotiation and consensus among the stakeholders offers the potential to cope with the issues and to support the sustainability of the river landscape in Van. This article is an examination of the limitations and opportunities of a collaborative approach to hydroelectric energy generation planning in Van. With this aim, following a description of the landscape characteristics, the area was evaluated for its importance in landscape conservation and attractiveness for hydroelectric energy generation. The stakeholders' roles, their influence, and conflicts in hydropower planning were analyzed and assessed using qualitative procedures. Next, possible landscape changes and impacts that the hydroelectric plants may cause were identified. Based on the identified limitations and opportunities for active stakeholder participation in hydropower and landscape conservation, recommendations were provided for collaborative decision-making processes that would aim for sustainability of the river landscapes in Van.

Keywords: Collaborative decision making; conflict; landscape conservation; public participation; stakeholder analysis; system thinking.

Türkiye'de son 15 yılda, planlanan ve uygulanan hidro-elektrik santrallerinin sayısı önemli ölçüde artmıştır. Ancak, bu santrallerin planlandığı peyzajların doğal ve sosyo-kültürel yapısı, karar verme ve uygulama süreçlerinde büyük ölçüde göz ardı edilmektedir. Bu yaklaşım, ülkenin su kaynakları bakımından zengin bölgelerinde inşaa edilen hidro-elektrik santrallerin, söz konusu nehir peyzajları üzerinde olumsuz, tahrip edici etkileri ile sonuçlanmıştır. Bu süreç, birbiri ile uyuşmayan ihtiyaç ve taleplerine bağlı olarak suyun ve peyzajın yerel ve ulusal ilgi gruplarını çeşitli platformlarda karşı karşıya getirmiştir. Doğu Anadolu Bölgesi'nde yer alan Van ilindeki nehir peyzajları da, yakın gelecekte inşaa edilmek üzere, peyzajdaki karmaşıkilişkileri gözardı eden, çok sayıda nehir tipi hidro-elektrik santralin planlanmışolmasına bağlı olarak benzer tehditler ve anlaşmazlıklar ile karşı karşıyadır. Ancak yine de, ilgi gruplarının aktif katılımına olanak veren, bu gruplar arasında müzakereyi ve uzlaşmayı teşvik eden, kolaboratif karar verme yaklaşımı söz konusu anlaşmazlıkların çözümüne ve Van’ın nehir peyzajlarının sürdürülebilirliğine katkı sağlayabilecek potansiyeller sunmaktadır. Makale, Van ilinin nehir peyzajlarındaki hidro-enerji üretimi planlaması sürecinde, kolaboratif yaklaşımın önündeki sınırlılkları ve olanakları sorgulamaktadır. Bu kapsamda, ilin peyzaj karakteristiklerinin ve temel süreçlerinin tanımlanmasının ardından, alan, peyzaj koruma açısından önemi, hidro-enerji üretimi bakımından çekiciliği ve mevcut çevre sorunları açısından değerlendirilmiştir. Bu değerlendirme aşamasında aynı zamanda, ilgi gruplarının hidro-enerji planlamasındaki rolleri, etkileri ve çatışma konularına yönelik niteliksel analiz ve değerlendirmeler yapılmıştır. Ardından, ildeki mevcut ve öneri hidro-elektrik santrallerin, nehir peyzajlarında neden olacağı değişimler ve bu değişimlerin olumsuz etkileri tanımlanmıştır. Sonuç olarak, hidro-enerji üretimi ve peyzaj korumada aktif ilgi grubu katıımının önündeki sınırlııklar ve olanaklar çerçevesinde, Van ilindeki nehir peyzajlarının sürdürülebilirliği için geliştirilebilecek kolaboratif karar verme süreçleri için öneriler sunulmuştur.

Anahtar sözcükler: Kolaboratif karar üretimi; çatışma; peyzaj koruma; halkın katılımı; ilgi grubu analizi; sistem düşüncesi.

Department of Landscape Architecture, Van Yüzüncü Yıl University Faculty of Architecture and Design, Van, Turkey

Article arrival date: March 19, 2017 - Accepted for publication: September 25, 2017

Correspondence: Emel BAYLAN. e-mail: emelbaylan@yyu.edu.tr

๑ 2017 Yıldız Teknik Üniversitesi Mimarlık Fakültesi - ๑ 2017 Yıldız Technical University, Faculty of Architecture 


\section{Introduction}

Due to global population increase and increasing diversity in human demands, energy need of societies and countries are continuously rising. Global, regional and local environmental problems and degradation of landscapes are forcing countries to meet the energy needs of their societies through renewable resources (Wüstenhagen et al., 2007). Nonetheless, the landscapes where renewable energy production facilities were built began experiencing negative impacts on their ecological, economical and socio-cultural processes (Martin, 2011). Therefore, while it is seen as one of the core requirements for development, energy generating from renewable resources has conversely become a threat on the sustainability, as the process turned out to be a driving factor of degradation in landscapes (Buchy and Hoverman, 2000; Bojórquez-Tapia et al., 2004; Reed, 2008; Selman, 2010). As a result, these kinds of approaches may also cause alteration or loss of distinctive and authentic characteristics of local landscapes and result conflicts among landscapes' stakeholders (Antrop, 2005; Stephenson, 2008).

Therefore, as a consequence of systemic relations between the landscape domains, changes in environment and their impacts should also be considered of systemic nature. Since 1980s, during the implementation of hydroelectric power plant projects (HEPPs), displacement of local communities and degradation of the natural-cultural characteristics of river landscapes and local livelihoods have, in many cases, resulted in opposition of the local communities and environmental groups in several countries (Devine-Wright, 2005; Warren et al., 2005). As a consequence, the notion of community involvement has been recognized to be of importance for social acceptance of renewable energy generation implementations, as well as resolutions for conflicts.

The main causes of the conflicts and problems associated with HEPPs and related landscapes arise mainly from the "traditional planning approach", which is dominated by the "top-down decision making" process. This approach and related processes are usually guided by experts and bureaucrats, while the socio-cultural values of landscapes and local stakeholders are neglected with the assumption that all the data are readily accessible and that all the potential results are predictable by experts (Gleick, 2003; Lachapelle et al., 2003; Peterson et al., 2003; Pahl-Wostl, 2009). The general intention in the participation mechanisms that only allow passive participation is to meet the legal obligations. Today, it has been widely accepted that top-down decision making in hydro-energy management projects is an unsuitable approach, especially considering the challenge of answering present and future demands of local societies in a democratic and sustainable man- ner. To address these issues, it has been recognized that hydro-energy planning and related natural resource management processes are not only technical processes, but they should also include a social aspect through an active participatory/collaborative decision making processes, beginning from the early planning phases of all renewable energy generation programs (Gleick, 2003; Giordano et al., 2007; Wüstenhagen et al., 2007; Pahl-Wostl et al., 2009; Martin, 2011).

The core and main characteristics of collaborative processes that consider the varying perspectives, values and interests of different stakeholders are (a) transparent decision making and conflict mediation processes, (b) shared goals that are based on negotiation and consensus, which are guided by shared values through shared working between a wide range of stakeholders on a given planning and management issue and (c) equal voice of stakeholders in the decision making (Arnstein, 1969; Selin and Chavez, 1995; Healey, 2003, Innes and Booher, 2010; Dijkstra et al., 2011). In this regard, in order to define the framework of a "collaborative decision making for hydro-energy planning", identification and assessment of (a) hydro-energy stakeholders' interests and needs, (b) potential conflicts between the stakeholders, (c) the ways of communication and (d) potential collaboration strategies for a shared goal is required.

Due to being rich in terms of water resources, river landscapes in the province of Van are confronted with degradation and stakeholder conflicts as a result of randomly-planned, multiple hydro-electric plant installations. Currently, within the provincial border of Van, additional to existing ones, more than 70 hydro-electric plants are planned for installation on the main rivers and streams, like Zilan, Hoşap, Çatak and Bahçesaray. The regulation and fragmentation of these rivers through power plants will create systemic changes that will impact the functions of the relatively unexploited river landscapes in the province. As such, ecological, socio-cultural and local economic impacts of these plants will be a burden to both to the local people and to the future generations.

While it is indeed quite difficult to solve such complex conflicts related to hydro-power generation, collaborative decision making approach offers opportunities in resolution of such conflict issues, aiming a commitment by the stakeholders to reach a mutually acceptable decision for the sake of sustainability of river landscapes. With that in mind, this article examines the stakeholders' opportunities and limitations for a collaborative approach in decision making processes for hydro-energy generation on the river landscapes in the province of Van.

In this context, following an overview on stakeholder participation issues in hydro-electric power plant planning 
in national scale, the first iteration of Steinitz's Geodesign framework (Steinitz, 2012) that is based on systemic thinking was applied in order to display the natural and socio-cultural-economic characteristics of Van landscape with regard to hydro-energy planning and landscape conservation in the province. Stakeholder and conflict analyses were adapted into the framework in order to identify the stakeholders' role in hydro-energy planning in the province and conflicting issues among the stakeholders. Stakeholder and conflict analyses that were based on structured interviews with the representatives of the local stakeholders and on the review of official reports. Identified stakeholders of hydro-energy and landscape were categorized according to their level of influence in decision making about HEPPs and their level of interest/ support/opposition in hydro-energy generation in Van. A qualitative research approach was employed in displaying the conflict causes and conflict types between the stakeholders, based on the data obtained through interviews and the stakeholder analysis. Based on the results of above mentioned analyses, some recommendations are formulated for collaborative working strategies between the stakeholders for the sustainability of the river landscapes of Van.

Unlike previous research on renewable energy and landscapes (e.g. Zoellner et al., 2008; Blaschke et al. 2013), the system thinking approach was applied in this study to provide a systematic understanding on the current status of Van landscape for collaborative hydro-energy planning and landscape conservation. In this study, different from previous research on conflict issues on hydro-energy generation, river landscapes, stakeholder participation (e.g. Karjalainen and Järvikoski, 2010; Diduck et al., 2013), research on geodesign and collaborative planning (e.g. Hayek et al., 2016; Slotterback et al., 2016), the stakeholder analysis, stakeholder quadrant and conflict analysis that enable to understand the integrated, overall picture of the opportunities and limitations that shape the collaborative processes were applied. Moreover, various causes and types of conflicts related with hydro-energy planning, natural resource and landscape management were analyzed and displayed in the study different from de Groot (2006) which only considers the conflicts between landscape functions that were described as pressures on and degradation of landscape functions as a result of their over use. Also, unlike from the above mentioned research that mainly focused on single hydro-energy projects, in this study it was tried to give an overall picture of the landscape resources, current and planned hydro-power projects, the strategies for landscape conservation, economic development and collaborative planning opportunities and limitations in the provincial context.

\section{Characteristics of the Decision Making for Hydro-Energy Generation in Turkey}

Due to her geographical location and biophysical landscape characteristics, Turkey has a high potential in terms of renewable energy resources of solar, wind, geothermal and hydropower energies. In order to meet the energy need of the country, renewable energy production has been promoted by governments as an alternative to fossil resources in Turkey since the beginning of 2000's (Kılıç, 2011). Today, the most commonly used and invested renewable energy resource in Turkey is the hydro-energy. The privatization of the energy production, have provided diverse opportunities for private sector to invest on hydroenergy all around the country (Kılıç, 2011; Koç and Şenel, 2013). In 2013 , approximately $25 \%$ of the electricity generation from renewable resources was based on hydraulic resources, with a rate of $19 \%$ from dams and $6 \%$ from rivertype hydropower plants. The aim is to make use of all the exploitable hydropower potentials by 2023 in the country (Ülgen et al., 2011; Koç and Şenel, 2013; Anonymous, 2014a). As such, 478 HEPPs were built and are currently operating in 69 provinces, and 1050 additional plants are planned to be built in 61 provinces in the country (Acar and Doğan, 2008; Kural, 2014). Consequently, river landscapes, associated ecosystems, and local communities are under threat of irreversible degradations and losses in the project areas.

When the distribution of electric energy production in the country is analyzed on the basis of the provinces, it is determined that Van has a total production of 156297.58 $\mathrm{MWh}$ and $0.06 \%$ of the total electricity production in the country and it is 65th among 81 provinces. On the basis of the installed power of the energy production, Van province has $0.09 \%$ of the installed power of the country with $66,82 \mathrm{MW}$ installed power. In this respect, the province ranks 68th among the 81 provinces (Anonymous, 2017). The amount of hydraulic energy produced in Van in 2016 was 53873 kWh (VEDAŞ, 2017), which accounts for $0.08 \%$ of the hydraulic energy ( 67.3 billion $\mathrm{kWh}$ ) produced throughout the country in the same year. When the distribution of invoiced electricity consumption is analyzed, it is seen that Van is in the 48th among the 81 provinces in the country with the consumption amount of $899.703,71$ MWh (0.42\%) (Anonymous, 2017). In the light of this data, the contribution of Van to electricity production in Turkey can be regarded as low but according to the electricity consumption in the province, the installed power of the province can be regarded as enough to meet the needs throughout the province.

The main legislative tool related with landscape conservation and stakeholder participation in the decision making for HEPPs in the country is the "Environmental Impact 
Assessment" (EIA) regulation. According to the amendments in this regulation (2008), EIA is a requirement for the HEPPs with the installed capacities of $25 \mathrm{MW}$ and higher. For the hydroelectric power plants with the installed capacity of $0.5-25 \mathrm{MW}$, the decision on the necessity of EIA is delegated to the Provincial Directorates of Environment and Urbanization (Uzun, 2011). Following the review of project proposals by the provincial directorates, public participation meetings are organized by the directorates and project owners in the project areas. These meetings, however, have limited to information sharing with local stakeholders, and are mostly about the benefits of the plants. According to the regulation, public participation and information-sharing meetings are not required for the projects between 0.5 to $25 \mathrm{MW}$ hydro-energy productions (Uzun, 2011; Ürker and Çobanoğlu, 2012).

Besides the above mentioned issues, most of the EIA works on HEPPs are based on office work only, and they are mainly focused on the biophysical characteristics of the subject landscape. The potential impacts of the projects on the local community are either completely neglected or inadequately assessed. Other important weaknesses in HEPP planning are the lack of integrated basin management approach and the cumulative impact assessments of the HEPP projects on the river basins.

As a result, construction of a hydroelectric power plant has become a source for conflicts between stakeholders like (a) national institutions responsible for landscape conservation and water and energy resources management, (b) energy and construction companies, (c) local people and (d) environmental groups in Turkey; particularly in the last 10 years.

\section{Material and Methods}

In order to understand the current conditions of the study area and to identify the limitations and opportunities for a collaborative decision making process for hydroenergy generation in Van based on systemic thinking, first iteration of Steinitz's Geodesign framework (Steinitz, 2012) was applied in this study. In this context, six questions that shape the Steinitz's framework were adapted during the research (Figure 1).

Following the description of the natural and socio-cultural landscape characteristics of Van, major biophysical, economic and social processes, and the relations among the landscape processes, were described in the context of second question. Landscape characteristics in the area were then evaluated for their attractiveness and potentials for hydro-energy generation and landscape conservation in the context of third question. Also in this step, current and potential environmental problems in the area were evaluated. Finally, in order to inform the decision phase

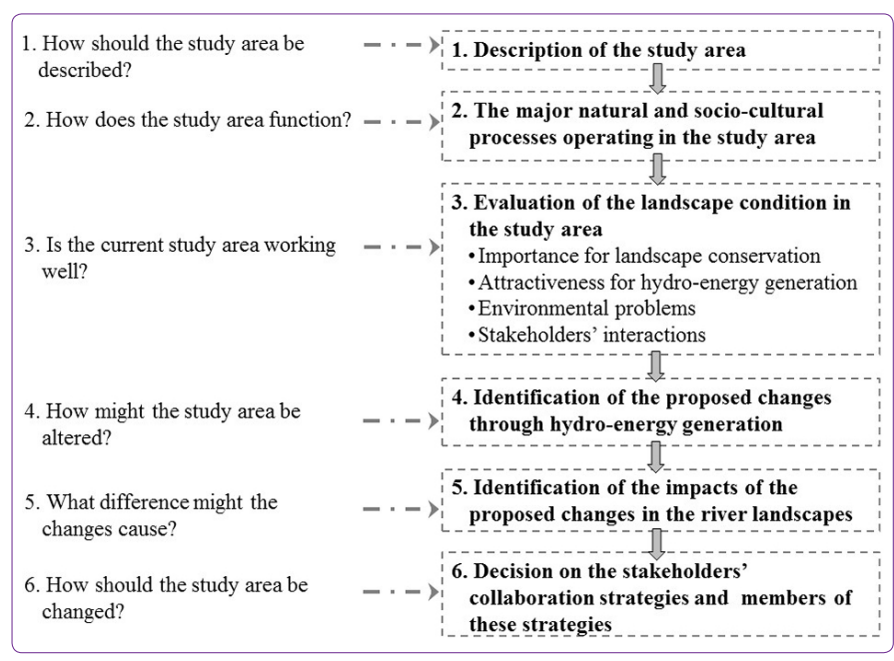

Figure 1. Steps that were followed during the study (based on Steinitz 2012).

(Step 6) on stakeholder interactions and collaborative decision making strategies, the stakeholder and conflict analyses were employed.

\section{Stakeholder Analysis}

In order to inform the Step 6, the current and potential stakeholders, their roles in a decision making process in hydro-energy generation planning, and local stakeholders' view on HEPPs were analyzed through structured interviews and review of the legal instruments. Structured interviews were held separately in June 2016 with 25 technical and managerial representatives from the Metropolitan Municipality of Van Province, district municipalities, provincial directorates of ministries related to environment, urbanization and nature conservation the chamber of architects and engineers, Law Society of Van and finally, local environmental civil society organizations (CSOs) in Van. Interviewees were asked to identify; the potential stakeholders, their influence (power)/interest level in the planning phase of HEPPs; their support for HEPPs in the province, and to state the conflicting issues between the stated stakeholders related to HEPPs in Van.

Based on the data obtained by interviews, identified stakeholders were mapped on a quadrant (Bryson, 2004; Ackermann and Eden, 2011; Olendar, 2007) according to their level of influence and interests (high, medium or low). Finally, based on the interest/influence stakeholder quadrant map and categorization of identified stakeholders, a stakeholder engagement strategy was defined to guide future collaborations to improve the HEPP policy to a more sensitive approach to landscape sustainability in Van.

\section{Conflict Analysis}

A qualitative research approach was also employed in exploring how various conflict causes resulted in different 
conflict types, based on the data obtained through interviews and the stakeholder analysis. To identify the types of conflict among stakeholders, "the circle of conflict" (Moore, 1995) was utilized and conflicts were categorized in five types as interests, structural, value, data, and relationship.

Also in the fourth step, in order to identify the possible landscape changes through the proposed HEPPs and development strategies in the "2014-2023 Regional Plan for Van Province" were evaluated. In the fifth step, following the description of the major changes foreseen for the province, potential impacts of hydro energy generation on the river landscapes in Van were described. Finally in the decision phase, based on the information gathered in the previous steps, potential structures and strategies for collaborative decision making processes for hydro-energy generation in the province was discussed.

\section{Site Description}

The area is located in the easternmost region of eastern Anatolia, centered in the basin of Lake Van. While the west of Van is surrounded by Van Lake, it has a border to Iran on the east (Figure 2). Northern and southern regions are covered by high volcanic mountains with an average altitude of $1725 \mathrm{~m}$. The east of the Province is covered by high plateaus. The whole provincial area is $21,823 \mathrm{~km}^{2}$, including the Van Lake. The area covered by the natural lakes is $393,632 \mathrm{ha}$, and the area of rivers and streams is 20,907 ha. $19.5 \%$ of the total land area is agricultural area, $71 \%$ is grassland and pasture, $1 \%$ is forest and $8.5 \%$ is distributed as other lands (Kılıç et al., 2006; Anonymous, 2013).

The territory has continuously been inhabited since prehistoric times by Urartians, Byzantians, the Seljuks Turks, the Mongols, Persians, and Ottomans (Kılıç et al., 2006). As of 2015 Van Province Census, 1.096.397 people reside within the Province and it is one of the least developed provinces of Turkey in terms of socio-economical parameters (Anonymous, 2014b).

\section{Results}

The Major Landscape Processes in the Study Area

Major landscape processes that shape the hydro-energy generation in the province are the topography, hydrology, geology and climate. The climate in the province is continental and considered as semi-arid, even though the rich surface water resources like rivers, and lakes. Van has a dynamic topography and landform with the high elevation variance, steep slopes, high plateaus and with the numerous valleys on the north-east and east of the Lake Van.

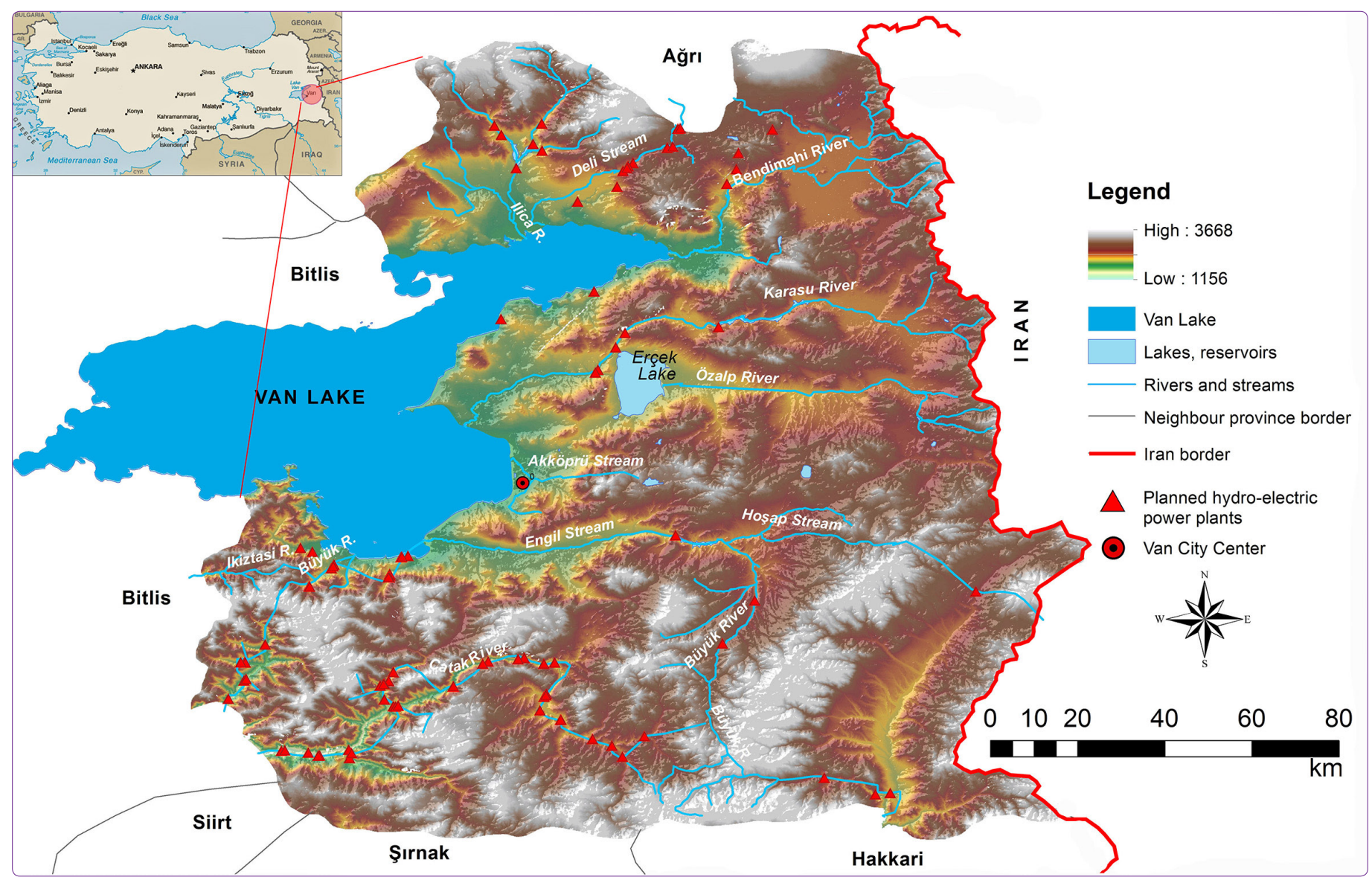

Figure 2. Geographical location of Van Province. 
Bio-geophysical landscape characteristics of the area form diverse habitats, which include alpine steps, wetlands, coastal habitats, rocky mountains, most of which accompanied by agricultural areas and rural settlements.

Due to this landscape characteristics, the province has a rich endemism, and critically endangered and vulnerable flora and fauna species both globally and regionally, so that, 16 Important Nature Areas were defined in the province (Eken et al., 2006). Most of these areas contain major rivers and streams, which will supposedly provide water for the planned hydro-electric power plants. The main economic activity in the area is livestock breeding, combined with limited vegetative production. Other economic activities include temporary labors in service sector, and civil service employment (Anonymous, 2013). The region has a high seismic activity, and the experienced earthquakes had a negative impact on the socio-cultural and economic development of the locale. Along with these natural processes, due to geographical location of the province, rich historical and cultural properties, migrations, security and smuggling problems and its human resource capacity are also amongst the primary processes that shape the in socio-cultural and economic landscape. Furthermore, the problems of population increase and unplanned land-use are rather prominently evident in Van.

\section{Evaluation of the Landscape Condition}

The unique and diverse landscape characteristics have formed rich and unique natural and cultural values which should be protected and managed in a sustainable manner. The almost untouched natural character render the area an impressive locale for eco-tourism, and thereby a primary candidate as a nature conservation area. The area is also a significant locale for culture tourism, since it has a rich cultural heritage due to being a host for numerous civilizations since the ancient times. Nature and heritage conservation efforts in the area however, currently are unreasonably lacking. For example, there are no nature conservation measures for the important natural areas where the aforementioned HEPP projects are planned or for the wetlands that will be affected from the river flow change as a result of hydro-energy generation. The effect of semi-arid climactic characteristics, further with relatively long winters, regional security problems and a rather insufficient agricultural infrastructure, the region's agricultural production suffers; which in turn jars its economic development.

Even though the province of Van has a relatively lower average precipitation and stream volume, due to its topographical properties and rivers with long streams, it becomes attractive to produce hydro-energy with microHEPP projects. Besides this, the fact that multiple HEPP projects were suggested on the same river in cases of Çatak, Bahçesaray, Zilan, Deliçay, Bendimahi and Büyük streams and their various branches, is an indication that all these HEPP projects are being planned without an integrated basin management approach and cumulative impact assessments.

In addition to these, interviews and observations reveal that there is an unsustainable land use approach in the region. Uncoordinated and uncooperative, sometimes hostile relationships between stakeholders worsen the current problems and increase the risks for the entire landscape in the region.

\section{The Stakeholders' Role in Hydro-Energy Planning}

A wide range of stakeholders that might participate in the decision making process for HEPPs in the province were identified. These stakeholders consist mainly of (a) local authorities, (b) local and provincial units of governmental institutions, (c) chambers and CSOs that work on water resources, environment, nature conservation and agriculture, and (d) private sector entities that work on HEPPs (Table 1). Based on different reasons, these stakeholders' opposition and support for HEPP constructions in the province vary. Among these reasons are institutional goals, short term economic benefits in national, local and individual levels, and assigned values and meanings to rivers and associated landscapes.

The analysis on the level of influence and interest of stakeholders in the decision making for HEPPs indicate that the national and provincial level units of governmental institutions which are responsible with water resources development, nature conservation, and urbanization in the country, along with the local authorities that represent state, have a high influence. Also, the private sector companies in hydro- energy production have significant influence and interest levels.

Local authorities like municipalities and village headmen, local community, farmers, low capacity CSOs have low influence power, although they will directly and strongly be affected by the outcomes of the projects (Figure 3 and 4).

The interviews have revealed that the EIA procedures for the planned HEPPs in the province were mostly made exclusively from office, without actual field surveys and public participation mechanisms in the region. The interviews have also indicated that information flow to the local stakeholders was either very low or completely nonexistent during decision making phases of the planned projects. Along with these, interviews and observations reveal that there is a lack of human resources capacity and lack of awareness on landscape conservation and public participation among most of the local stakeholders. The key challenges voiced in the interviews were the neglect of local actors and lack of coordination among the stakeholders. Besides all these, due to the negative relationships 
Table 1. Stakeholders of decision making phase for HEPPs in Van, their level of interest/influence and level of support/opposition for HPPs

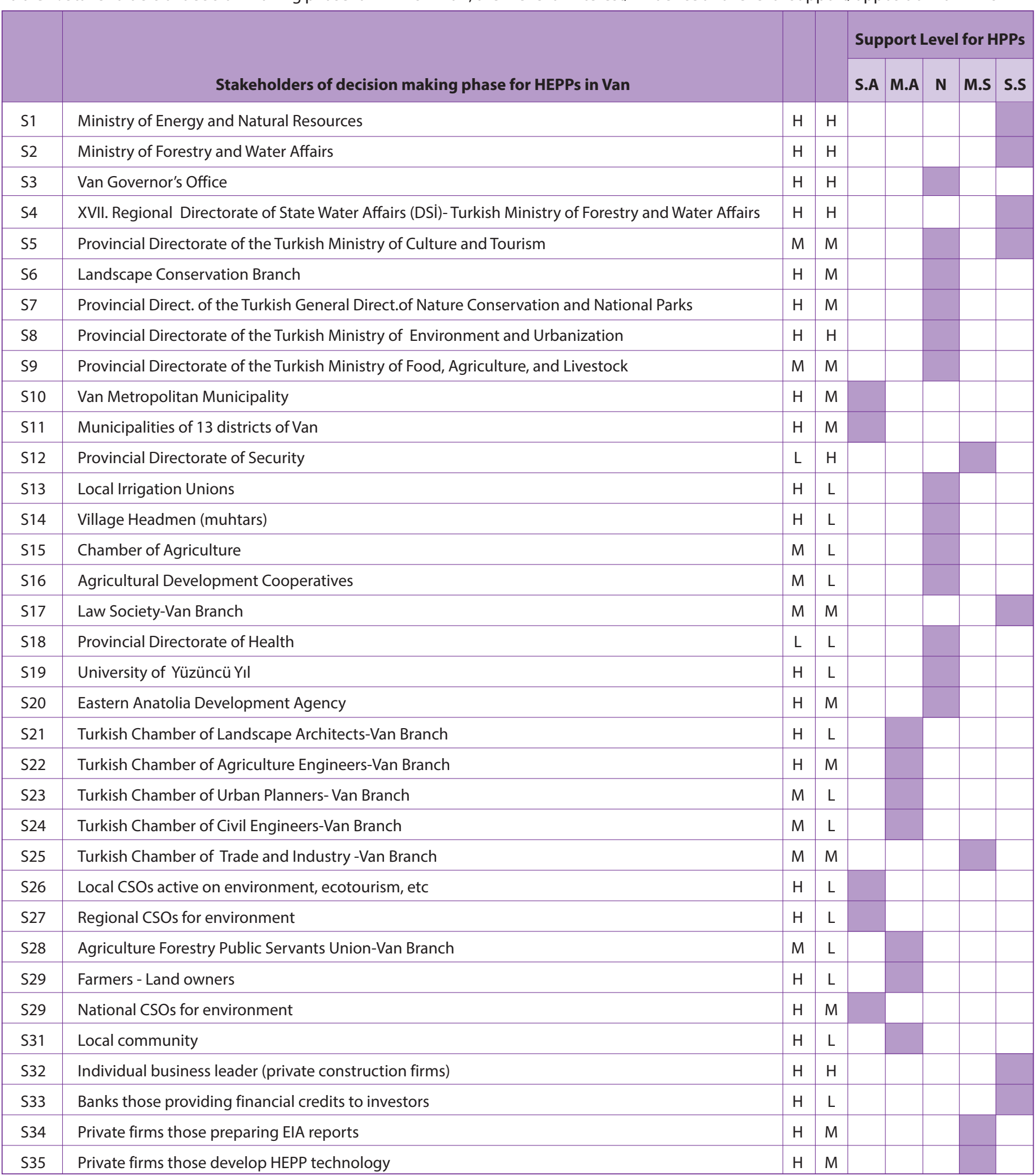

H: High; M: Moderate; L: Low; S.A: Strongly Against; M.A: Moderately Against; N: Neutral; M.S: Moderately Supportive; S.S: Strongly Supportive.

and disputes in the past, along with the continuing conflicts (Figure 5), these stakeholders are not sufficiently engaged and, trust is weak among them. As a result, analyses have revealed that the interactive communication and collective working culture between the stakeholders of HEPPs are weak in the province. 


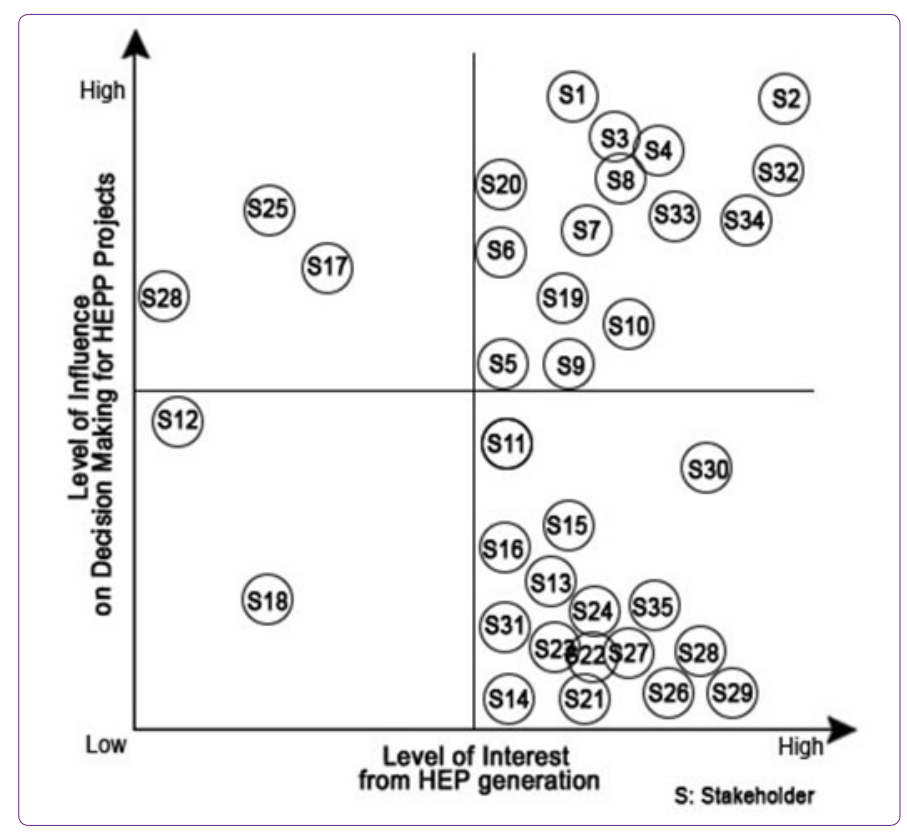

Figure 3. Quadrant of the stakeholders' level of influence on decision making for HEPPs and level of interest in hydro-energy generation.

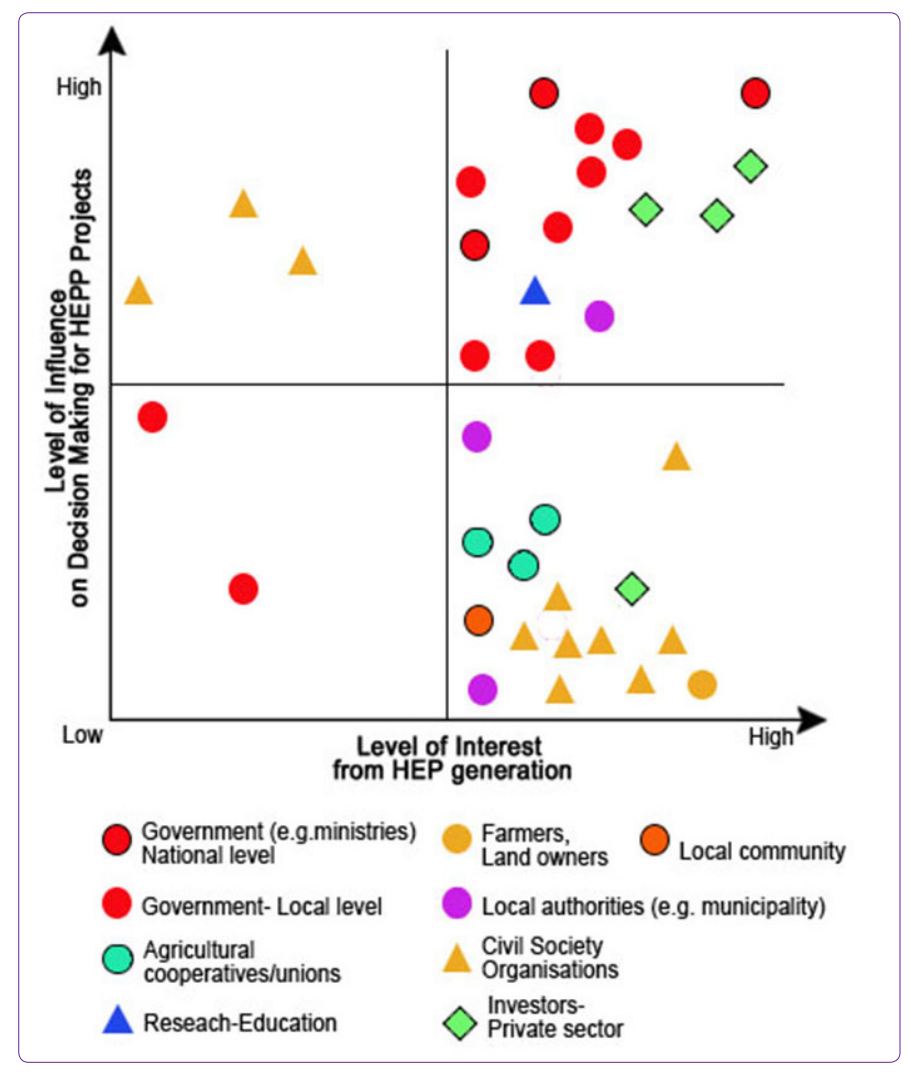

Figure 4. Stakeholder categories in the level of influence on decision making for HEPPs and level of interest in hydro-energy generation.

The Proposed Changes and Their Possible Results On the River Landscapes

The leading plan amongst many others which will have impact on the river landscapes within the province of Van is the "2014-2023 Period TRB2 Sector Regional Plan". This plan defines "Economic Transformation and Growth" and "Strong Community" visions, related to environmental, socio-cultural and economic development for the province. Within the context of "Economic Transformation and Growth" vision, some of the goals with the potential to impact the river landscapes of Van are specified below;

- Improving the agricultural production;

- Efficient use of natural resources, sustainable rural development,

- Utilization of renewable energy sources,

- Tourism development,

- Sustainable environmental management;

o natural resources management

o protection of vulnerable ecosystems and biological diversity (Anonymous, 2014c).

The plan states that it is paramount that the construction of all the licensed hydroelectric power plants for the region be sped up and the construction of those which are under planning start as soon as possible in order to achieve complete utilization of all the hydroelectric potential around Van until the year 2023. Furthermore, surveys and assessments to find out water resources in the region that have hydroelectric potential, and preparation of a "Hydroelectric Energy Potential Atlas", are amongst the foreseen projects (Anonymous, 2014c).

70 HEPPs that are already licensed/ planned will most definitely have the greatest impact on sustainability of the river landscapes in the province in the near future. These proposed plants vary in energy production capacity, in ownership, and in construction type. In terms of location, many of the proposed plants are placed either on the same river or on its tributaries.

Related to public participation, the strategies for institutional capacity development and building collective working awareness under the "Strong Community" vision offer some opportunities in decision making process for landscape and energy sectors.

\section{Potential Impacts of Proposed Development Goals and HEPPs}

The strategy of utilization of renewable energy sources, along with the planned HEPPs constructions and their operation, has the following potential threats and impacts on the river landscapes in Van;

- Degradation in natural hydraulic cycles; erosion, degradation and habitat fragmentation in the riparian ecosystems, and wetlands,

- Changes in the land drainage levels, or the ability to avoid floods, 


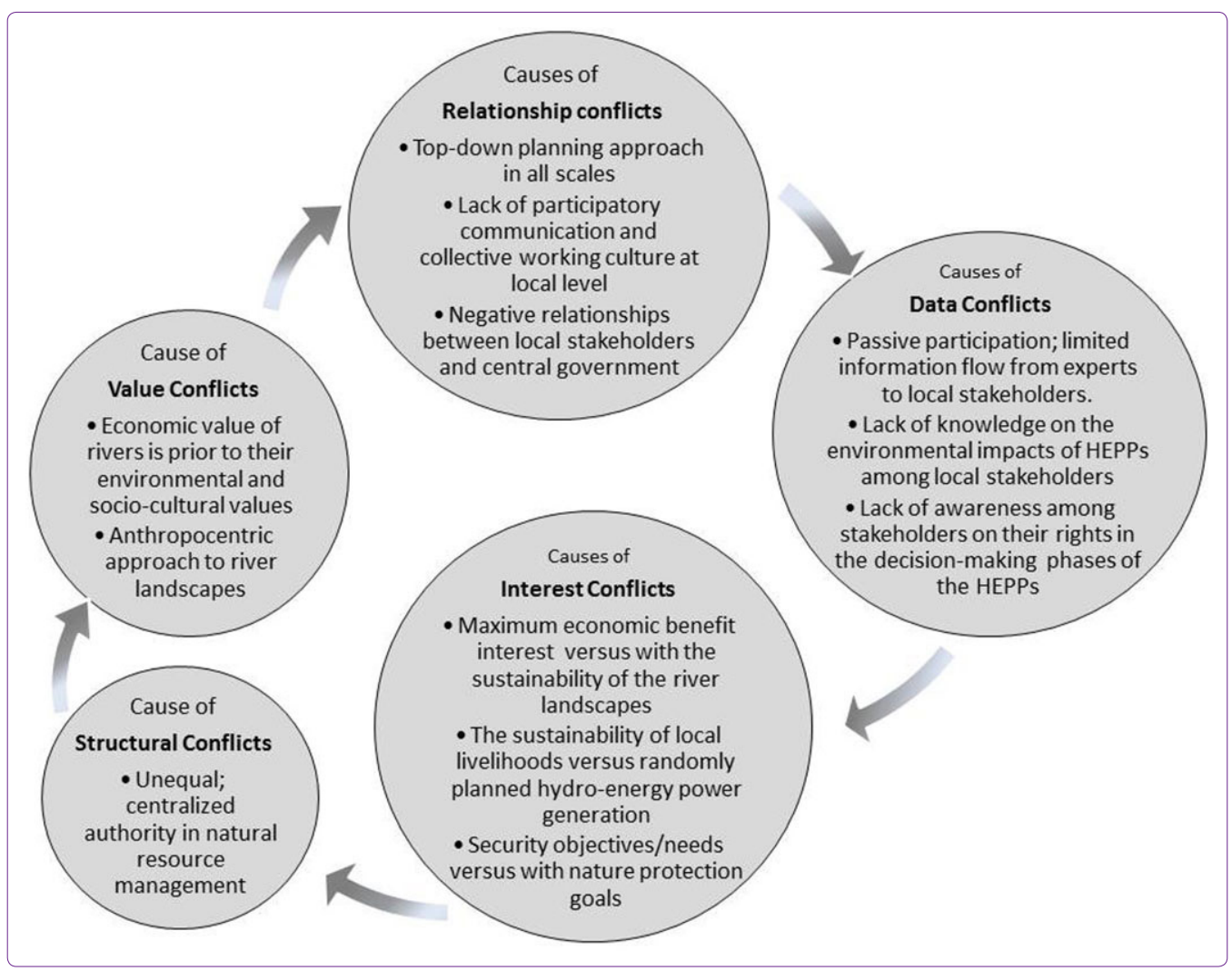

Figure 5. Types and causes of conflicts among hydro-energy and landscape stakeholders in Van.

- Pollution on, and loss/decrease of, portable and agricultural water resources,

- Degradation of visual landscape quality,

- Damages on livelihoods of rural communities; displacement of local communities;

- Degradation on cultural characteristics of landscape,

- Damages on the potential resources of alternative economic activities -such as ecotourism,

- Conflicts between the local and national stakeholders.

Specifically, due to having multiple hydroelectric power plants planned on the main rivers and their streams, the water basins of Çatak, Bahçesaray, Ilıca, Deli and Karasu Rivers will face the above mentioned threats and impacts. Due to either being within or connected to these river basins, Çatak and Mukus Valleys' Important Natural Areas, the wetlands like Bendimahi, Karasu, Engil deltas, Edremit and Çelebibağ Marshes, and the associated INAs will also be under threat. Muradiye Waterfall is already experiencing the impacts of the hydro-electric power plant which was installed on the Bendimahi River. All these threats and potential influences will undoubtedly have direct and indirect negative effects on the goals and strategies of agricultural development, sustainable environment management, sustainable growth and improved tourism defined for the region around the city.
Based on the findings of stakeholder analysis and interest/influence quadrant, general framework for stakeholder engagement strategies for collaborative decision making in hydro-energy generation in Van are recommended in Figure 6. In this context, the governmental bodies in

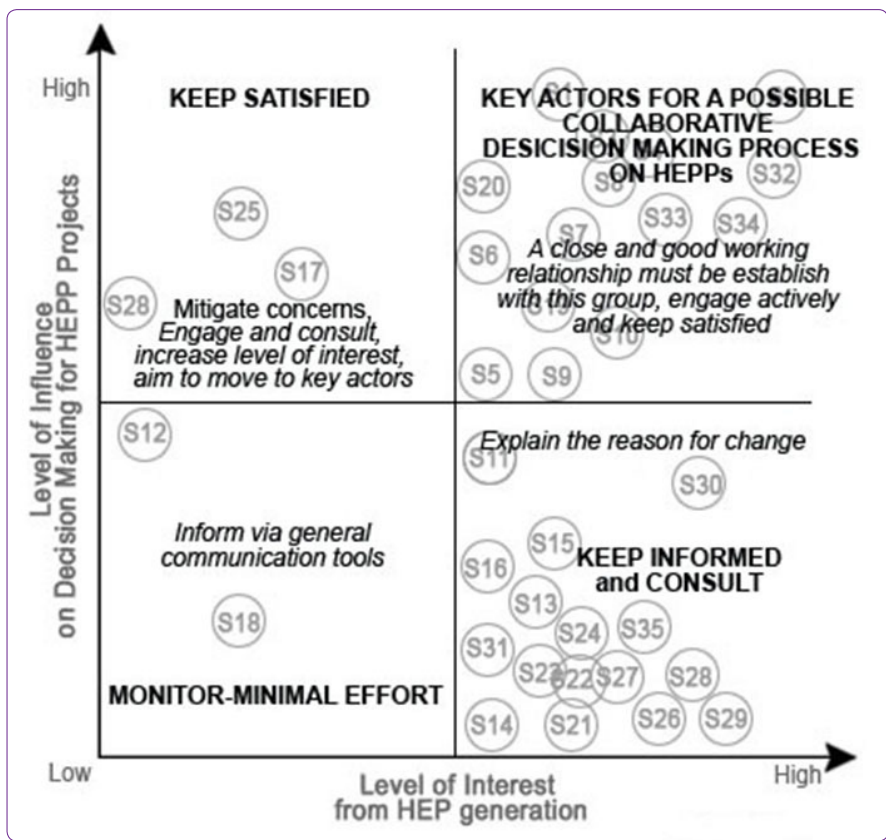

Figure 6. Stakeholder management strategies for the sustainability of river landscapes in Van. 
national, regional and provincial scale, along with private sector stakeholders, should form the core group that might be in collaboration for the decision making process for HEPPs in Van. The characteristics of the stakeholders with high interest/high influence and the conflicts among them suggest that policy and organizational level collaborations are needed to achieve the sustainability of the river landscapes in the province and to resolution of the conflicts. The stakeholders with high interest but low influence need to be informed and to be consulted about the process and the future outcomes of HEPPs in Van by the core collaboration group. The stakeholders in this group need to be supported and developed in terms of human resources capacity, environmental awareness and collective working culture.

\section{Conclusion and Discussion}

The conflicts in recent decades between stakeholders' of renewable energy production and landscapes have underlined the need for collaborative decision making. Collaboration provides a framework for active participation of stakeholders in land-use planning, the landscape conservation and energy generation; yet in practice, there are substantial barriers and difficulties preventing full collaboration. In this article, opportunities and limitations for collaborations to realize active participation in hydro-energy generation for Van Province were examined. For this purpose, stakeholders' influence/interests in the decisionmaking processes for hydro-energy planning, local stakeholders' views on HEPPs, and conflicts among the water and landscape stakeholders were examined through a qualitative research following the description of the landscape characteristics and future development goals in Van. The paper contributes to collaborative natural resource management and collaborative landscape planning science by integrating the analyses such as stakeholder, influence/interest and conflict that are common in stakeholder engagement research and practice into the first iteration of Geodesign framework different from the previous studies (e.g. Hayek et al., 2016; Slotterback et al., 2016) to build a deeper understanding of the stakeholder conditions for developing a collaborative decision making. Thus, the adapted first iteration of geodesign framework provided a systemic thinking and understanding on the natural landscape and besides, the social landscape of the province.

The findings point to a variety of challenges in establishing a collaborative decision making for hydro-energy planning and landscape conservation within the under-developed rural context of the province. The significance of the paper is that it was displayed the interrelated and complex nature of the stakeholders' relations with each other and with the landscape, the causes of conflicts between them and also, the inequalities between the stakeholders in de- cision making which in turn shape the opportunities and limitations for collaborative approaches in decision making for hydro-energy generation on the river landscapes of Van. The results show that the main limitations for collaborative approaches in decision making processes for hydro-energy generation in the province are the structural and value conflicts in natural resource management between the stakeholders. These conflicts and their causes also aggravate the past and current conflicts and besides, the data conflicts between the state and the non-governmental actors in national and local levels. Moreover, the low capacity of the local actors and their very low interest in participation into environmental issues weaken the use of already limited opportunities for collaboration. As such, these stakeholders face with losing their already limited level influence in the decision making for hydro-energy, landscape and other public related issues.

Analyses reveal that natural functions and potentials of the river landscapes and related local livelihoods in Van are under threat of degradation from the proposed hydroenergy generation facilities in combination with current land use practices. Due to the systemic interrelations in the landscapes, the impacts of HEPPs installations on the visual quality of the river landscapes will also negatively impact the eco-tourism potential. Therefore, the goal of "providing the use of renewable energy resources" are in conflict with "tourism development" and "sustainable environment management" goals for the province, similar to many other landscapes as stated by Warren et al. (2005) and Sæpórsdóttir (2012). Findings on conflict types also confirm that short term economic interests and long term sustainability interests in Van are in conflict. This suggests that Van landscape, which has higher potentials for ecotourism, nature conservation and agricultural production than it is for hydro-energy production, has been sacrificed for the production of hydropower. However, during the interviews and in the reports examined, no information or evidence was found that revealed the economic benefits of the planned hydro-electricity generation such as cheap electricity, improvement in social life or economic growth in the province or in the region unlike displayed in the previous researches (e.g: Tullos et al., 2013; Murni et al., 2012). These suggest that the public interest and the contribution to the local economy of the planned HEPPs in Van are controversial. Furthermore, non-integrated strategies for the above mentioned sectors point the possible increase in unsustainable land uses of Van landscape in the future.

One of the major causes for the land-use conflicts and limited information-sharing among the stakeholders is the top-down decision making approach for HEPPs in the national scale. It seems like the top-down, passive-participa- 
tion decision making and implementation culture -which was specified as the crux of the problem for the practice of collaborative decision making for hydro-energy generation is unfortunately dominant in Van as well. Even though the goal of "strong community" was defined in the regional development plan, related goals and strategies don't go beyond passive participation procedures like consultation and manipulation which inhibit the collaborative decision making. This also manifested itself in the absence of consideration of the local non-governmental organizations and local people during the EIA processes that were conducted for the planned hydroelectric power plant in the province.

Besides, the under-developed economic, socio-cultural and institutional levels of the province and the stakeholders' as a whole were also identified as another important weakness for developing active-participation in both hydro-energy production and landscape conservation in Van. Therefore, as mentioned similarly by Imperial (2005), stakeholders' characteristics in national and provincial context and their capacities are two of the constraints of collaborative decision making for hydro-energy planning and landscape conservation. As a result, improvement of socio-cultural infrastructure is a priority necessity, which would create potential for collaboration in decision making among the local and national stakeholders.

These findings also suggest that perception of water sources and environment that is based on anthropocentric view are among of the main drivers and main limitations of collaborative decision making for hydro-energy planning in the region, as is the case in the whole country.

To address these conflicts and challenges with a collaborative process among the stakeholders, "sustainability of river landscapes in Van" should be recognized as the shared goal and a multiparty task. As such, recently revised water management policy and related regulations in the country that emphasis the integrated basin management approach may be utilized to support the collaboration and conflict resolutions in the form of collaborative watershed organizations for sustainability of river landscapes, like as mentioned in the studies of Bark et al. (2012) and Akamani (2016). Within the provincial borders, Çatak, Bahçesaray, Ilıca, Bendimahi and Karasu river basins have the highest priority for such kind of collaborative organizations due to the threats they are facing.

Consequently, the need to move from one-way communication to effective dialogue both during the planning and the construction phases of energy generation should be regarded as a shared responsibility by all the stakeholders. In order to develop effective dialogue and to avoid and/or to resolve the conflicts, it is critical to build relationships with a wide range of stakeholders, including adversaries. These kinds of relationships would also support social-learning and create processes based on communicative action in the region. As stated by Rist et al. (2007), although they are long term efforts, new formations of such collaborative decision making at local levels will lead to improvement of relations between the stakeholders and to improvement in the quality of decisions, which will contribute to conflict resolution and the development of rural areas like Van. As a signatory country of the European Landscape Convention that mention "public participation", Turkey should also develop and adapt regulations on participation procedures into the national legislations on decision making for environment, water and energy. As such, along with social impact assessment procedure, active participation procedures that allow equal reflection of stakeholders' voice, needs and aspirations of local communities into the decision making phases for HEPPs and landscape conservation should be adapted into the legislations.

\section{References}

Acar, E. ve Doğan, A. (2008) “Türkiye'nin Rüzgar ve Hidrolik Enerji Potansiyeli ve Çevresel Etkilerinin Değerlendirilmesi", VII. Ulusal Temiz Enerji Sempozyumu Bildiri Kitabı UTES' 2008, 17-19 Aralık 2008, İstanbul, s. 675-682.

Ackermann, F. and Eden, C. (2011). "Strategic Management of Stakeholders: Theory and practice", Long Range Planning Vol 44 (3), p.179-196.

Akamani, K. (2016) “Adaptive Water Governance: Integrating the Human Dimensions into Water Resource Governance", Journal of Contemporary Water Research \& Education, Vol. 158, p. 2-18.

Arnstein, S.R. (1969) "A Ladder of Citizen Participation”, Journal of the American Planning Association, Vol. 35(4), p.216-224.

Antrop, M. (2005) "Why Landscapes of the Past Are Important for the Future", Landscape and Urban Planning, Vol. 70 (1-2), p.21-34.

Bark, H. R., Garrick E. D., Robinson J. C., Jackson, S. (2012) “Adaptive Basin Governance and The Prospects for Meeting Indigenous Water Claims", Journal of Environmental Science and Policy, Vol.19, p.169-177.

Blaschke, T., Biberacher, M., Gadocha, S., Schardinger, I. (2013)" 'Energy Landscapes': Meeting Energy Demands and Human Aspirations", Biomass and Bioenergy, Vol: 55, p. 3-16.

Bojórquez-Tapia, L.A., De La Cueva, H., Díaz, S., Melgarejo, D., Alcantar, G., Solares, M.J., Grobet, G., Cruz-Bello, G. (2004) "Environmental Conflicts and Nature Reserves: Redesigning Sierra San Pedro Martir National Park, Mexico", Biological Conservation, Vol. 117, p.111-126

Bryson, J.M. (2004) "What to Do When Stakeholders Matter: Stakeholder Identification and Analysis Techniques", Public Management Review, Vol. 6, p.21-53.

Buchy, M. and Hoverman, S. (2000) "Understanding Public Participation in Forest Planning: A Review", Forest Policy and Economics, Vol. 1 (1), p.15-25

Devine-Wright, P. (2005) "Local Aspects of UK Renewable Energy Development: Exploring Public Beliefs and Policy Implications", Local Environment, Vol. 10(1), p. 57-69. 
De Groot, R. (2006) “Function-Analysis and Valuation as A Tool To Assess Land Use Conflicts in Planning For Sustainable, MultiFunctional Landscapes", Landscape and Urban Planning, Vol. 75, p. $175-186$

Diduck, A. P., Pratap, D., Sinclair, A. J.,, Deane, S. (2013) "Perceptions of Impacts, Public Participation, and Learning in The Planning, Assessment and Mitigation of Two Hydroelectric Projects in Uttarakhand, India", Land Use Policy, Vol. 33, p.170-182.Dijkstra, A.M., Gutteling, J.M., Swart, J.A.A., Wieringa, N.F., van der Windt, H.J., Seydel, E.R. (2011) "Public Participation in Genomics Research in The Netherlands: Validating a Measurement Scale", Public Understanding of Science, Vol.20 (10), p. 1-13.

Eken, G., Bozdoğan, M., Isfendiyaroğlu, S., Kiliç, D.T., Lise, Y. (2006) Türkiye'nin Önemli Doğal Alanları, Ankara, Doğa Derneği Yayınları

Giordano, R., Passarella, G., Uricchio, F.V., Vurro, M. (2007) “Integrating Conflict Analysis and Consensus Reaching in a Decision Support System for Water Resource Management", Journal of Environmental Management, Vol. 84(2), 213-22.

Gleick, P.H. (2003) "Global Freshwater Resources: Soft-Path Solutions for The 21st Century", Science, Vol. 302, p.524-528.

Healey, P. (2003) "Collaborative Planning in Perspective", Planning Theory, Vol.2 (2), p.101-123.

Hayek, U. W., Von Wirth, T., Neuenschwander, N., Grêt-Regamey, A. (2016) "Organizing and Facilitating Geodesign Processes: Integrating Tools into Collaborative Design Processes for Urban Transformation", Landscape and Urban Planning, Vol. 156, p.59-70.Imperial, M. T. (2005) “Using Collaboration as a Governance Strategy-Lessons from Six Watershed Management Programs", Administration and Society, Vol. 37(3), p.281-320.

Innes, J.E. and Booher, D.E. (2010) Planning with Complexity: An Introduction to Collaborative Rationality for Public Policy, London and New York, Routledge Taylor \& Francis Group.

Karjalainen, T. P., Järvikoski, T. (2010) "Negotiating River Ecosystems: Impact Assessment and Conflict Mediation in the Cases of Hydro-Power Construction", Environmental Impact Assessment Review, Vol. 30(5), p.319-327.

Kılıç, S. (2006) Van Kültür ve Turizm Envanteri I - Tarihsel Değerler, İstanbul, Van İl Kültür ve Turizm Müdürlüğü. T. C. Van Valiliği.

Kılıç, F. Ç. (2011) "Türkiye'deki Yenilenebilir Enerjilerde Mevcut Durum ve Teşviklerindeki Son Gelişmeler", Engineer \& The Machinery Magazine, Vol. 614, p.103-115.

Koç, E. ve Şenel, M. C. (2013) “Dünyada ve Türkiye'de Enerji Durumu - Genel Değerlendirme", Mühendis ve Makine, Sayı. 54 (639), s. 32-44.

Lachapelle, R.P., McCool, F.S., Patterson, E.M. (2003) “Barriers to Effective Natural Resource Planning in a "Messy" World", Society \& Natural Resources, Vol. 16(6), p.473-490.

Martin, J. P. (2011) "Social Barriers to Renewable Energy Landscapes", Geographical Review, Vol. 101(2), p. 201-223.

Murni, S., Whale, J., Urmee, T., Davis, J., Harries, D. (2012) "The Role of Micro Hydro Power Systems in Remote Rural Electrification: A Case Study in The Bawan Valley, Borneo", Procedia Engineering, Vol.49, p.189-196.Olander, S. (2007) "Stakeholder Impact Analysis in Construction Project Management. Construction", Management and Economics, Vol. 25 (3), p. 277-287.
Pahl-Wostl, C., Sendzimir, J., Jeffrey, P. (2009) "Resources Management in Transition", Ecology and Society, Vol. 14(1), p.46.

Peterson, G.D., Carpenter, R.S., Brock, W.A. (2003) "Uncertainty and Management of Multi-State Ecosystems: An Apparently Rational Route to Collapse", Ecology, Vol. 84, p. 1403-1411.

Reed, S. M. (2008) "Stakeholder Participation for Environmental Management: A Literature Review", Biological Conservation, Vol. 141, p.2417-2431.

Rist, S., Chiddambaranathan, M., Escobar, C., Wiesmann, U., Zimmermann, A. (2007) "Moving From Sustainable Management to Sustainable Governance of Natural Resources: The Role of Social Learning Processes In Rural India, Bolivia and Mali", Journal of Rural Studies, Vol. 23, p. 23-37.

Selin, S. and Chavez, D. (1995) "Developing a Collaborative Model for Environmental Planning and Management", Environmental Management, Vol. 19 (2), p.189-195.

Selman, P. H. (2010) "Learning to Love the Landscapes of Carbon-Neutrality", Landscape Research, Vol. 35 (2), p.157-171.

Sæpórsdóttir, A. D. (2012) "Tourism and Power Plant Development: An Attempt to Solve Land Use Conflicts", Tourism Planning \& Development, Vol. 9 (4), p. 339-353.

Slotterback, C.S., Runck, B., Pitt, D.G.,Kne,L., Jordan, N.R., Mulla, D.J., Zerger, C., Reichenbach, M. (2016) “Collaborative Geodesign to Advance Multifunctional Landscapes", Landscape and Urban Planning, Vol.156,p. 71-80.

Steinitz, C. (2012) A Framework for GeoDesign: Changing Geography By Design, Redlands, Calif. PB. : ESRI

Stephenson, J. (2008) "The Cultural Values Model: An Integrated Approach to Values in Landscapes", Landscape and Urban Planning, Vol. 84, p.127-139.

Tullos, D. D., Foster-Moore, E., Magee, D., Tilt, B., Wolf, A.T., Schmitt, E., Gassert, F., Kibler. K. (2013) "Biophysical, Socioeconomic, and Geopolitical Vulnerabilities to Hydropower Development on the Nu River, China", Ecology and Society, Vol. 18 (3):16. Retrieved from https://www.ecologyandsociety.org/vol18/iss3/art16/ [Accessed 06 August 2017]

Uzun, O. (2011) “Hidro Elektrik Santraller (HES) ve Çevresel Etki Değerlendirmesi (ÇED) Düzce Örneği”, Düzce Üniversitesi Orman Fakültesi Ormancılık Dergisi, Sayı: 7 (2), s.1-13.

Ürker, O. ve Çobanoğlu, N. (2012) "Türkiye'de Hidroelektrik Santraller'in Durumu (HES'ler) ve Çevre Politikalari Bağlamında Değerlendirilmesi", Ankara Üniversitesi Sosyal Bilimler Enstitüsü Dergisi, Sayı: 3(2), s. 65-88.

Warren, C.R., Lumsden, C., O’Dowd, S., Birnie, R.V. (2005) “'Green on green': public perceptions of wind power in Scotland and Ireland", Journal of Environmental Planning and Management, Vol. 48 (6), p.851-873.

Wüstenhagen, R., Wolsink, M., Bürer, M.J. (2007) "Social Acceptance of Renewable Energy Innovation: An Introduction to the Concept", Energy Policy, Vol.35 (5), p.2683-2691.

Zoellner, J., Schweizer-Reis, P., Wemheuer, C. (2008) "Public Acceptance of Renewable Energies: Results from Case Studies in Germany", Energy Policy, Vol. 36 (11), p. 4136. Policy

\section{Web Documents/References}

Anonymous. (2013) "Van il Çevre Durum Raporu”, Retrieved from http://www.csb.gov.tr/db/ced/editordosya/Van_icdr2013. pdf [Accessed 16 February 2016]

Anonymous. (2014a) "2014 Faaliyet Raporu”, T.C. Enerji ve Tabii 
Kaynaklar Bakanlığı, Retrieved from http://www.enerji.gov. tr/File/?path=ROOT\%2f1 \%2fDocuments \%2fFaaliyet\%20 Raporu\%2f2014.pdf [Accessed 07 July 2016]

Anonymous. (2014b) "Van Ili Stratejik Mekansal Planı, Bölüm I: Van İli ve ilç̧eleri Mevcut Durum Analizi", İkarya Danışmanlık. Retrieved from http://www.van.bel.tr/media/documents/ pdf/37409_I.\%20etap-Mevcut\%20Durum \%20Analizi.pdf [Accessed 07 July 2016]

Anonymous. (2014c) "2014-2023 Dönemi TRB2 Bölgesi Bölge Planı", Retrieved from http://www.daka.org.tr/panel/files/ files/yayinlar/trb2_2014_2023_bp.pdf [Accessed 07 July 2016]

Anonymous. (2017a) "Elektrik Piyasasi 2016 Yili Piyasa Gelişim Raporu", T.C. Enerji Piyasası Düzenleme Kurumu, Strateji Geliştirme Dairesi Başkanlığı, Ankara. Retrieved from http:// www.epdk.org.tr/TR/Dokumanlar/Elektrik/YayinlarRaporlar/ ElektrikPiyasasiGelisimRaporu [Accessed 06 September 2016]

Anonymous. (2017b) "Van ili 2016 yılı hidroelektrik üretim miktarı verileri (basılmamış)" Van Gölü Elektrik Dağıtım A.Ş. Retrieved from http://www.vedas.com.tr/bilgi-merkezi [Accessed 06 September 2017]

Devine-Wright, P. (2007) "Reconsidering Public Attitudes and Public Acceptance of Renewable Energy Technologies: A
Critical Review", published by the School of Environment and Development, University of Manchester, Oxford Road, Manchester M13 9PL, UK. Retrieved from http://www.sed. manchester.ac.uk/research/ beyond_nimbyism/ [Accessed 05 August 2016]

Kural, B. (2014) "HES'ler; Faaliyettekiler, Planlananlar, Durdurulanlar", Retrieved from http://bianet.org/bianet/ cevre/153518-hes-ler-faaliyettekiler-planlananlar durdurulanlar [Accessed 10 April 2015]

Moore, C. (1995) "What is conflict?", Eds.: C. W. Moore, R.Jayasundere, M. Thirunavukarasu The Mediation Process: Trainee's Manual Community Mediation Programme, CDR Associates, Boulder, Colorado USA, and Flaurie Storie of the Canadian International Institute of Applied Negotiation, Ottawa, Canada, Retrieved from http://moj.gov.lk/web/images/pdf/trainee_english_final_med_process.pdf. [Accessed 21 September 2016]

Ülgen, H., Alp, E., Zeydanlı, U., Kurt, B., Balkız, Ö. (2011) “Report on the Ecological Impacts of Small Hydropower Plants in Turkey and Recommendations to the Gold Standard Foundation", Nature Conservation Centre, Retrieved from http:// www.dkm.org.tr/Dosyalar/YayinDosya_N5Bi7EyO.pdf [Accessed 05 May 2015] 